\title{
Obituary
}

\section{Prof. J. D. Cormack, C.B.E., C.M.G.}

$\mathbf{J}^{\mathrm{o}}$ OHN DEWAR CORMACK was born in 1870 , a son of Alexander Cormack, rector of Dumbarton Academy. His career as an undergraduato at the University of Glasgow was a distinguished one, and those of his fellow students who are left still remember the successes and the prizes he gained at his class examinations.

In 1892, Cormack proceeded to Yorkshire College, Leeds, where he was appointed as lecturer in engineering subjects, specialising chiefly in electrical work. In 1896 he returned to Glasgow as assistant to the late Prof. Barr, and for some years acted as lecturer in electrical engineering. In 1901 he was appointed to the chair of mechanical engineering at University College, London, where he remained for twelve years. He took a prominent part in the affairs of the University of London and did conspicuous service on the engineering examining boards for both internal and external students.

In 1903, Cormack succeeded the late Prof. Barr as regius professor of eivil engineering and mechanies at the University of Glasgow. He was welcomed back to his old college with enthusiasm, for his reputation as an exceptionally fine lecturer and teacher, as well as his prowess as a Rugby player and a golfer were well remembered. His appointment coincided with the affiliation to the University of the Royal Technical College, when much anxiety was felt over the possible troubles that might arise in the changes that would inevitably take place in the teaching and examination systems of both institutions. That the affiliation has been a great success was in a great measure due to the enthusiasm with which Prof. Cormack entered into the closer association of the two great engineering schools.

With the outbreak of war in 1914, Prof. Cormack gave up for the time his university work and placed his engineering knowledge at the disposal of the nation. His labours were largely in the aeronautical branch of war service. He occupied in succession the positions of chief contracts officer of military aeronautics, director of aircraft supply and equipment, and assistant controller of the aeronautical departments. From 1917 until 1919, he was in the United States as a member of the British Mission. In addition to the honours indicated by C.B.E., and C.M.G., he had the decoration of Chevalier of the Legion of Honour conferred upon him by the French Government; he was also an honorary brigadier general and honorary group captain R.A.F.

In 1932, Prof. Cormack was elected as president of the Institution of Engineers and Shipbuilders in Scotland, thus following in the footsteps of his famous predecessors in the engineering chair-Rankine, James Thomson, and Barr. His election indicated the esteem in which he was held by the Clydeside engineers and shipbuilders, and his term of office, which had only expired a few months before his death, will be long remembered for the quiet and efficient manner in which the business of both council and general meetings was conducted.

Prof. Cormack's death was sudden and unexpected. During the summer months he had been receiving medical attention, but he had taken up his university duties at the beginning of the session and was lecturing until a day or two before his death. A chill rapidly developed into pneumonia, and he died on Saturday, November 30.

As a professor of engineering Prof. Cormack was more attracted by teaching and administrative work than by experimental research. His students will long remember him for his lucid, well-delivered lectures as well as for the kindly interest he took in both their studies and college activities, and the efforts he made to start them in their engineering careers.

\section{Dr. William MacDonald}

The death of Dr. W. MaeDonald at the age of sixty years removes an enthusiast for South Africa and a firm believer in her future as the seat of a white civilisation. A Scotsman by birth and education, he spent some time studying in the United States and in France before settling in South Africa. There he realised that the prosperity produced by the recently discovered gold mines could only be stabilised by a concomitant development of agriculture, and he became the leading protagonist of his time for the dry-farming system. His two books"Dry Farming" and "The Conquest of the Desert"focused attention on what was, and probably always will be, one of the greatest obstacles to intensive agriculture in South Africa, and although modern policy is directed, perhaps wisely, towards encouraging extensive animal husbandry rather than the more intensive dry farming advocated by Dr. MacDonald, the influence of his work can be traced in the way that policy has developed. The growth of the citrus industry owes not a little to his encouragement in its early days. He had some of the enthusiasm of Cecil Rhodes for colonisation, and became director of the South African Land Settlement Bureau which did much to promote immigration before the Great War. He was proprietor, editor and a frequent contributor to the Agricultural Journal of South Africa, and was the prime mover in the institution of a faculty of agriculture at the University of Pretoria.

While MacDonald's life's work was in agriculture, he also took a deep interest in the mining industry, realising that this must be the real foundation on which a South African civilisation would be built. $\mathrm{He}$ is best known in England for his book "The Romance of the Rand" (1933), in which he gives a vivid account of the discovery of gold by his friend, Mr. F. Struben, and the early struggles of the pioneers. 